\title{
The Role of Dual Red Imaging in Gastric Endoscopic Submucosal Dissection
}

\author{
In Kyung Yoo and Joo Young Cho \\ Department of Gastroenterology, Cha Bundang Medical Center, Cha University College of Medicine, Seongnam, Korea
}

See "Clinical Usefulness of Dual Red Imaging in Gastric Endoscopic Submucosal Dissection: A Pilot Study" by Naoki Yorita, Shiro Oka, Shinji Tanaka, et al., on page 54-59.

Endoscopic submucosal dissection (ESD) is a widely used non-invasive treatment for gastric lesions, including early gastric cancer and dysplasia. ${ }^{1}$ Novel techniques have been developed to reduce serious adverse events associated with ESD, such as bleeding and perforation. In such a scenario, endoscopic hemostasis is an important technique used to prevent distinct complexities. When intraprocedural active bleeding cannot be controlled, the procedure time might be longer and the risk of perforation increases. ${ }^{2}$ Occasionally, emergency intervention or surgery with excessive transfusion might be necessary in case of severe bleeding. ${ }^{3}$

Recently, image-enhanced endoscopy (IEE) has been developed, which encompasses various methods of enhancing contrast during endoscopy using optical and/or electronic methods. ${ }^{4}$ A new IEE technique, dual red imaging (DRI), has been introduced that captures images using three kinds of wavelengths: $500 \mathrm{~nm}, 600 \mathrm{~nm}$, and $630 \mathrm{~nm}$. The $540 \mathrm{~nm}$ light can visualize small blood vessels in shallow tissue, and the latter two $(600 \mathrm{~nm}$ and $630 \mathrm{~nm}$ ) can penetrate deep into the tissue and reflect with little attenuation. The displayed image

Received: January 6, 2020 Revised: January 12, 2020

Accepted: January 12, 2020

Correspondence: Joo Young Cho

Department of Gastroenterology, Cha Bundang Medical Center, Cha University College of Medicine, 59 Yatap-ro, Bundang-gu, Seongnam 13496, Korea Tel: +82-31-780-5641, Fax: +82-32-780-5005, E-mail: cjy6695@naver.com ORCID: https://orcid.org/0000-0002-7182-5806

(c) This is an Open Access article distributed under the terms of the Creative Commons Attribution Non-Commercial License (http://creativecommons.org/ licenses/by-nc/3.0) which permits unrestricted non-commercial use, distribution, and reproduction in any medium, provided the original work is properly cited. shows that the $600 \mathrm{~nm}$ light is significantly more attenuated than the $630 \mathrm{~nm}$ light, which enhances the visibility of the deep vessels. ${ }^{5}$ When blood vessels are absent, the reflected light is visualized with low attenuation; however, the reflected $600 \mathrm{~nm}$ light becomes highly attenuated in the presence of highly concentrated blood when compared to the presence of low-concentrated blood. Thus, the reflected image becomes reddish with the concomitant occurrence of a color contrast. This enables visualization of thick vessels, allowing instant discovery of bleeding points.

Yorita et al. ${ }^{6}$ showed that DRI enhanced the visibility of bleeding spots during gastric ESD, hence reducing the need for coagulation. Thus, they suggested that DRI could be a potentially safe method to perform gastric ESD. ${ }^{7}$ This study had several limitations. The results were based on a small sample size with a retrospective review of images. Moreover, there was a selection bias, which is an inevitable limitation of a retrospective study.

There was a report on the role of DRI in colorectal ESD that stated that DRI improved the visibility of arteries in the submucosal layer, ${ }^{5}$ thereby enhancing the speed and safety of the procedure. Notably, it has been reported to be useful in predicting the prognosis of ulcerative colitis and the depth of esophageal varices, especially with respect to submucosal fatty tissue. $^{8,9}$

In this study, the authors have demonstrated DRI as a useful approach in gastric ESD, especially under unfavorable conditions such as blood pooling. Additional studies with a larger sample size will be needed to verify the role of DRI in gastric ESD. 


\section{Conflicts of Interest}

The authors have no financial conflicts of interest.

ORCID

In Kyung Yoo: https://orcid.org/0000-0003-0909-339X

\section{REFERENCES}

1. Jeon SW, Jung MK, Cho CM, et al. Predictors of immediate bleeding during endoscopic submucosal dissection in gastric lesions. Surg Endosc 2009;23:1974-1979.

2. Yamamoto Y, Kikuchi D, Nagami Y, et al. Management of adverse events related to endoscopic resection of upper gastrointestinal neoplasms: review of the literature and recommendations from experts. Dig Endosc 2019;31 Suppl 1:4-20.

3. Tajiri H, Kitano S. Complications associated with endoscopic mucosal resection: definition of bleeding that can be viewed as accidental. Dig
Endosc 2004;16(Suppl 1):S134-S136.

4. Jang JY. The past, present, and future of image-enhanced endoscopy. Clin Endosc 2015;48:466-475.

5. Ninomiya Y, Oka S, Tanaka S, et al. Clinical impact of dual red imaging in colorectal endoscopic submucosal dissection: a pilot study. Therap Adv Gastroenterol 2016;9:679-683.

6. Yorita N, Oka S, Tanaka S, et al. Clinical usefulness of dual red imaging in gastric endoscopic submucosal dissection: a pilot study. Clin Endosc 2020;53:54-59.

7. Yahagi N, Horii J, Goto O, et al. Dual red imaging; a new endoscopic imaging technology for clear visualization of bleeding points in endoscopic submucosal dissection. Gastrointest Endosc 2014;79(5 Suppl):AB464.

8. Furuichi Y, Gotoda T, Kasai Y, et al. Role of dual red imaging to guide intravariceal sclerotherapy injection of esophageal varices (with videos). Gastrointest Endosc 2018;87:360-369.

9. Naganuma M, Yahagi N, Bessho R, et al. Evaluation of the severity of ulcerative colitis using endoscopic dual red imaging targeting deep vessels. Endosc Int Open 2017;5:E76-E82. 